\title{
vFLIP protects PC-12 cells from apoptosis induced by Sindbis virus: implications for the role of TNF- $\alpha$
}

\author{
R Sarid ${ }^{1,3}$, T Ben-Moshe ${ }^{1,3}$, G Kazimirsky ${ }^{1}, \mathrm{~S}$ Weisberg ${ }^{1}$, \\ E Appel ${ }^{1}$, D Kobiler ${ }^{2}$, S Lustig ${ }^{2}$ and C Brodie ${ }^{\star, 1}$ \\ ${ }^{1}$ Faculty of Life Sciences, Bar-Ilan University, Ramat-Gan, Israel 52900 \\ 2 Department of Infectious Diseases, Israel Institute for Biological Research, \\ Ness Ziona, Israel \\ ${ }^{3}$ These authors contributed equally to this study \\ * Corresponding author: C Brodie, Faculty of Life Sciences, Bar-Ilan University, \\ Ramat-Gan 52900, Israel. Tel: 972-3-5318266; Fax: 972-3-5350234; \\ E-mail: chaya@mail.biu.ac.il.
}

Received 2.4.01; revised 21.5.01; accepted 28.6.01 Edited by B Osborne

\begin{abstract}
Sindbis virus (SV) is an alphavirus used as a model for studying the pathogenesis of viral encephalitis. In this study we examined the effects and the mechanisms involved in the apoptosis induced by SV in PC-12 cells, and the role of a vFLIP in this process. Infection of PC-12 cells with a neurovirulent strain of SV, SVNI, induced cell apoptosis. Overexpression of vFLIP encoded by the HHV-8 or treatment with a caspase-8 inhibitor inhibited cell apoptosis. SVNI induced an increase in the expression of tumor necrosis factor $\alpha$ (TNF- $\alpha$ ), and pretreatment of the cells with an anti-TNF- $\alpha$ blocking antibody or with soluble TNF- $\alpha$ receptor abrogated the apoptotic effect of SVNI. Moreover, TNF- $\alpha$ R1 knockout mice were more resistant to the cytopathic effects of the virus as compared to control animals. Our results indicate that the apoptosis induced by SVNI is mediated by activation of caspase-8, and that TNF- $\alpha$ plays an important role in the apoptotic response. Cell Death and Differentiation (2001) 8, 1224-1231.
\end{abstract}

Keywords: Sindbis virus; tumor necrosis factor $\alpha$ (TNF- $\alpha$ ); apoptosis; FLIP; caspase-8

Abbreviations: SV, Sindbis virus; TNF- $\alpha$, tumor necrosis factor $\alpha$; FLIP, FLICE inhibitory protein

\section{Introduction}

Apoptosis is a genetically preprogrammed controlled process of cell death, which plays an important role in organogenesis and tissue homeostasis. ${ }^{1}$ Various cellular signals, including growth factor withdrawal, receptor ligation, drug treatment, radiation and virus infection induce apoptotic cell death. ${ }^{2-4}$ Viruses have been reported to modify the ability of the cells to undergo apoptosis. ${ }^{5,6}$ In most cases, cell apoptosis following viral infection is used as a defense mechanism by the host cells, since it limits virus production and prevents neighboring cells from being infected by progeny virions. ${ }^{5}$ Thus, most animal viruses have evolved strategies to evade or delay early apoptosis by induction of endogenous anti-apoptotic cellular proteins or by insertion of anti-apoptotic genes encoded by the viruses themselves. ${ }^{5}$ In these cases the cells may survive viral infection, and persistent virus infection can be established. Conversely, a growing number of viruses actively induce apoptosis at late stages of infection, thus allowing to disseminate progeny viruses while also avoiding host immune inflammatory and immune responses. ${ }^{5}$ Such virally induced apoptosis most likely contributes to pathogenesis of virus infection.

Sindbis virus (SV), a neurotropic alphavirus of the Togaviridae, is a classical model to demonstrate the central role of apoptosis in the virus infectious process. ${ }^{7}$ Experimental SV infections of cultured cells result in either persistent or lytic infection depending on the cell type and the virus strain. ${ }^{7,8}$ SV lytic infection triggers programmed cell death, however overexpressed inhibitors of apoptosis, such as the BCL-2 protein, may protect cultured cells from virus-induced apoptosis of certain SV strains and shift the infectious cycle from a lytic to a persistent phase. ${ }^{9}$ Similarly, overexpression of antiapoptotic genes (e.g., bcl-2, beclin, and $\mathrm{crmA}$ ) in virally infected neurons in vivo reduces mice mortality from SV infection. ${ }^{10}$ Furthermore, induction of apoptosis in neurons of mouse brains and spinal cords correlates with the neurovirulence of the virus strain and with mortality in mice, indicating that apoptosis may have a primary role in the pathogenesis of the virus. ${ }^{11}$ Recently, based on the usage of synthetic peptide caspase inhibitors and CrmA (a cowpox virus-encoded inhibitor of caspase-1), SV-induced apoptosis was reported to be mediated by activation of the death pathway utilized by Fas and TNF- $\alpha$, through the activation of caspases. ${ }^{5,12}$

Apoptosis induced by ligation of death receptors, such as the tumor necrosis factor receptor-1 (TNFR-1), TRAMP, and CD95 (Fas/Apo-1) is associated with the formation of a death-inducing signaling complex (DISC). ${ }^{13}$ Death receptors commonly contain a 'death domain' (DD) within their cytoplasmic portion, which can recruit an adapter molecule that contains a DD and a 'death effector domain' (DED). ${ }^{13,14}$ The resulting signaling complex triggers activation of the caspase apoptotic pathway through interaction of DED motifs of the adapter molecules with corresponding motifs of the death protease FLICE (caspase-8/Mch5/ $\mathrm{MACH}) .{ }^{13,15} \mathrm{~A}$ new class of inhibitors of death receptormediated apoptosis, FLICE-inhibitory proteins-FLIPs, was recently found to be encoded by several viruses ${ }^{16,17}$ and later as cellular proteins (termed also FLAME-1/CLARP/ MRIT/I-FLICE/CASH/Usurpin). ${ }^{18-20}$ FLIP proteins contain two DED domains (also present at the carboxyl terminus of FADD and in the amino terminus of FLICE),${ }^{17}$ however they appear to serve as dominant-negative inhibitors of FLICE activation by competing with effectors of this bridging network. 
In this study we examined the mechanisms involved in the apoptosis induced by a highly neurovirulent SV strain (SVNI) in PC-12 cells. ${ }^{21,22}$ We show that the apoptosis triggered by SVNI infection can be inhibited by the expression of vFLIP protein and that TNF- $\alpha$ plays a role in the apoptotic process.

\section{Results}

\section{Overexpression of vFLIP in PC-12 cells}

In a recent study it has been reported that SV induces apoptosis via a caspase-mediated CrmA sensitive pathway, thus suggesting similarity to the apoptotic pathway induced by members of the TNF-R superfamily. ${ }^{12}$ Since various members of the flip family have been reported to prevent cell apoptosis induced by this pathway ${ }^{17,19,23}$ we examined the effect of VFLIP encoded by the HHV-8 on the apoptosis induced by SVNI in PC-12 cells.

PC-12 cells were stably transfected with vFLIP expression plasmid tagged to His-tag or with an empty vector. To examine the vFLIP protein expression in the transfected cells, we analyzed by Western blot two pooled cultures and two different overexpressing clones for VFLIP as well as for the vector controls. Figure 1 illustrates a representative Western blot analysis of the vector control (CV1 and CV2), two clones of PC-12 cells overexpressing VFLIP (PC12Flip1 and PC12Flip6) and two-pooled VFLIP transfected cultures (PC12P1 and PC12P2). Using a rabbit antiHis antibody we detected a $26 \mathrm{kDa}$ band that appeared only in the clones expressing VFLIP, whereas no expression was observed in the control vector cells.

\section{vFLIP protects cells from apoptosis induced by TNF- $\alpha$ and SVNI}

Since VFLIP has been shown to inhibit TNF- $\alpha$ mediated apoptosis, we first examined the ability of VFLIP to protect PC-12 cells from apoptosis induced by TNF- $\alpha$. Treatment of the control vector cells or the parental PC-12 cells with
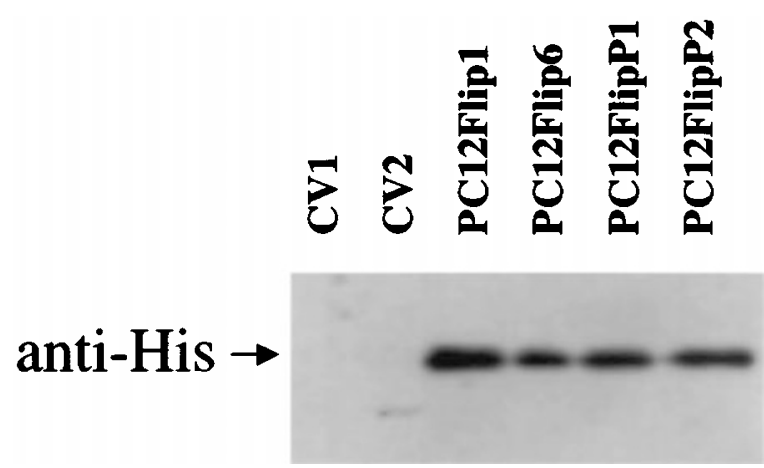

Figure 1 Overexpression of vFLIP in PC-12 cells. Stable Clones (PC12Flip1 and PC12Flip6) or pools (PC12P1 and PC12P2) of PC-12 cells overexpressing vFlip or the empty vector (CV) were harvested and subjected to SDS-PAGE and Western blot analysis. The membranes were probed with an anti-His antibody which recognizes the His-tag. The results represent one of three separate experiments, which gave similar results
TNF- $\alpha(60 \mathrm{ng} / \mathrm{ml})$ for $48 \mathrm{~h}$ induced cell apoptosis as determined by the anti-histone ELISA assay. In contrast, similar treatment of the PC12Flip1 and PC12Flip6 clones with TNF- $\alpha$ did not induce cell apoptosis (Figure 2A) and cell morphology was similar to that of untreated cells (data not shown).

We then examined the ability of VFLIP to protect cells from apoptosis induced by SVNI. Figure 2B and C illustrate the morphological appearance and the DNA analysis of cells transfected with the control vector and with vFlip (PC12Flip1 and PC12Flip6). Control vector cells infected with SVNI (5 M.O.I.) displayed typical morphological changes of apoptotic cells (Figure 2B). The cell bodies became rounded and the majority of the cells detached from the dish. In contrast, vFLIP overexpressing cells exhibited normal morphology in both control and SVNIinfected cells. Similar results were obtained using DNA analysis as assessed by propidium iodide staining. Thus, infection of control vector cells with SVNI resulted in apoptosis of $48 \%$ of the cells. In contrast, SVNI did not induce apoptosis in cells overexpressing vFLIP (Figure 2C). Similar results were obtained with anti-histone ELISA (data not shown).

\section{Replication of SVNI in cells overexpressing vFLIP}

To determine if vFLIP protects PC-12 cells from apoptosis by inhibiting virus replication, we performed plaque assay for measuring virus replication. PC-12 cells were infected with SVNI (5 M.O.I.) for 24 and $48 \mathrm{~h}$. Using plaque assay we found that the replication of SVNI in control vector cells or cells overexpressing VFLIP was comparable after 24 and $48 \mathrm{~h}$ (Table 1).

Immunofluorescent staining of the cells with anti-SV antibody indicated that infection with SVNI resulted in similar staining of the control vector and the VFLIP overexpressing cells (Table 1 ). Similar results were obtained with other clones of PC-12 cells overexpressing vFLIP (data not shown).

\section{Caspase-8 inhibition blocks SVNI-induced apoptosis}

Activation of different caspases is required for the effector phase during apoptosis. One of the possible targets of VFLIP is FLICE/caspase-8. ${ }^{16}$ To delineate the role of caspase-8 in SVNI-induced apoptosis, cells were incubated in the presence of the specific caspase- 8 inhibitor ZIETD-FMK ${ }^{24}$ for $1 \mathrm{~h}$ before virus infection and cell apoptosis was determined $48 \mathrm{~h}$ later. As presented in Figure 3, the caspase-8 inhibitor $(50 \mu \mathrm{M})$ reduced by $85 \%$ cell apoptosis induced by SVNI, implying that the activation of caspases is a central mechanism in SVNIinduced cell death. Higher levels of the inhibitor were toxic for the cells and induced cell death (data not shown). To determine the effect of Z-IETD-FMK on virus replication, we performed plaque assay in cells infected with SVNI for 24 and $48 \mathrm{~h}$. As shown in Figure 3B, the caspase 8 inhibitor did not affect the replication of SVNI in either time point. 
$\mathbf{A}$

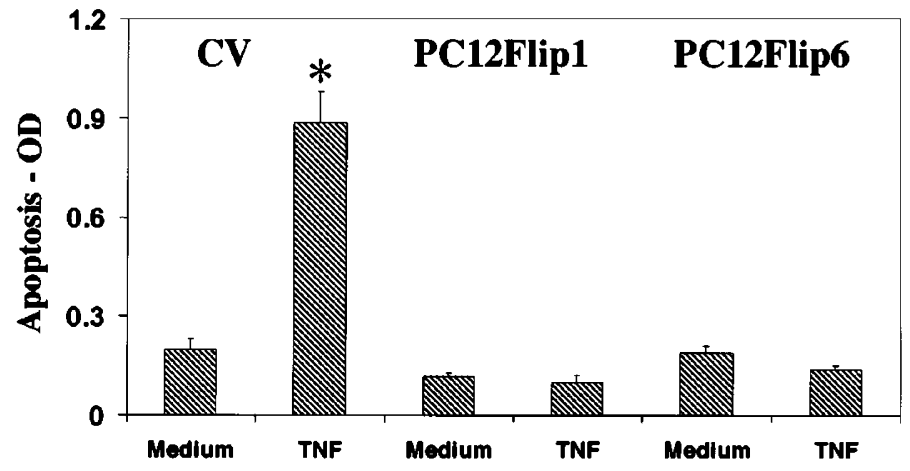

B
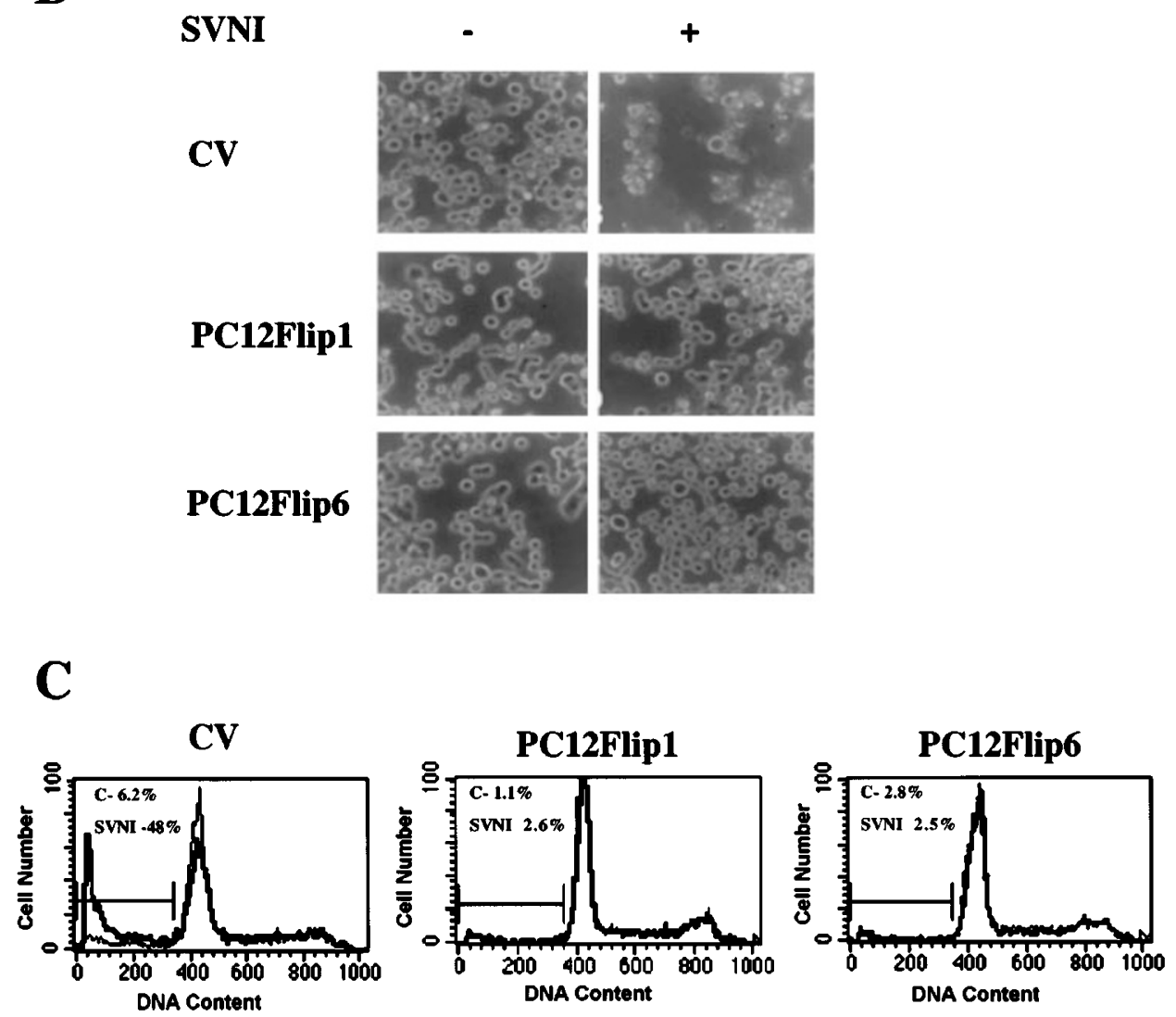

Figure 2 vFLIP protects PC-12 cells from TNF- $\alpha$ and SVNI-induced apoptosis. Cells overexpressing vFLIP or control vector cells were treated with TNF- $\alpha$ (60 ng/ $\mathrm{ml}$ ) for $48 \mathrm{~h} \mathrm{(A)} \mathrm{or} \mathrm{infected} \mathrm{with} \mathrm{SVNI} \mathrm{for} 48 \mathrm{~h} \mathrm{(B,C).} \mathrm{Cell} \mathrm{apoptosis} \mathrm{was} \mathrm{determined} \mathrm{by} \mathrm{ELISA} \mathrm{using} \mathrm{anti-histone} \mathrm{antibodies} \mathrm{(A)} \mathrm{or} \mathrm{by} \mathrm{staining} \mathrm{with} \mathrm{propidium} \mathrm{iodide}$ and FACS analysis (C). The morphology of the cells was evaluated by a phase contrast light microscope (B). The results represent that means \pm S.E. of three separate experiments. ${ }^{*} P<0.001$

Table 1 Infection and replication of SVN1 in PC-12 cell overexpressing control vector or vFlip

\begin{tabular}{|c|c|c|c|c|c|c|}
\hline & \multicolumn{3}{|c|}{ Vector control } & \multicolumn{3}{|c|}{ PC12Flip1 } \\
\hline & $5 \mathrm{~h}$ & $24 \mathrm{~h}$ & $48 \mathrm{~h}$ & $5 \mathrm{~h}$ & $24 \mathrm{~h}$ & $48 \mathrm{~h}$ \\
\hline P.F.U./ml & $8 \times 10^{5}$ & $2 \times 10^{7}$ & $6 \times 10^{7}$ & $6 \times 10^{5}$ & $9 \times 10^{6}$ & $2 \times 10^{7}$ \\
\hline Immunofluorescence (per cent positive cells) & & & $93.0 \pm 6.8$ & & & $82.5 \pm 7.5$ \\
\hline
\end{tabular}

PC-12 cells overexpressing control vector (CV) or v-Flip (PC12Flip1) were infected with SVNI (5 M.O.I.) for 5, 24 and 48 h. Virus replication was determined using plaque assay as described in Materials and Methods and immunofluorescence staining was performed using anti-SV antibody. The results represent the means $\pm S$.E. of three separate experiments 


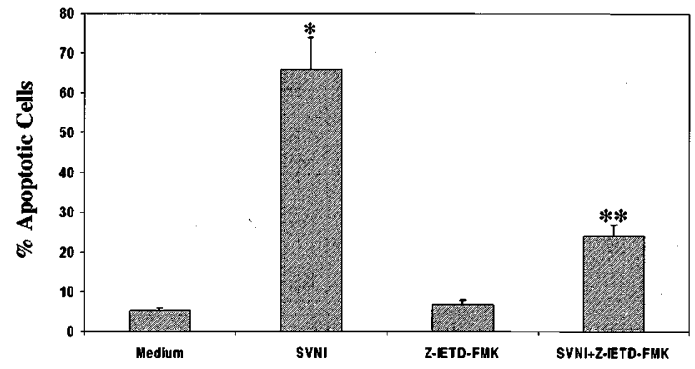

B

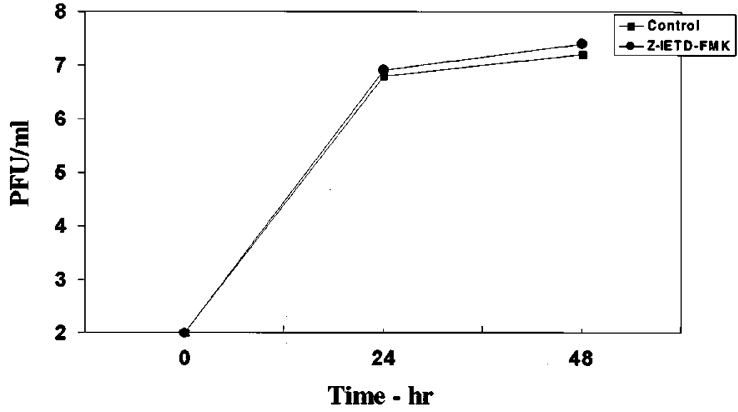

Figure 3 Effects of caspase-8 inhibitors on SVNI-induced apoptosis and on viral replication. PC-12 cells were treated with the caspase-8 inhibitor, Z-IETDFMK $(50 \mu \mathrm{M})$ for $1 \mathrm{~h}$ and were then infected with SVNI for $48 \mathrm{~h}$. Cell apoptosis was determined using propidium iodide and FACS analysis (A). SVNI replication in control and Z-IETD-FMK-treated cells was determined using plaque assay after 24 and $48 \mathrm{~h}(\mathrm{~B})$. The results represent the means $\pm S$.E. of three separate experiments. ${ }^{\star} P<0.001,{ }^{* *} P<0.002$

\section{SVNI induces an increase in TNF- $\alpha$ mRNA and TNF- $\alpha$ secretion in PC-12 cells}

In a recent study we reported that SVNI induced TNF- $\alpha$ production from glial cells, whereas a non-virulent strain, SVA had no significant effect on TNF- $\alpha$ production. ${ }^{25}$ Since TNF- $\alpha$ has been implicated as a mediator of cell apoptosis following virus infection, ${ }^{26}$ and since vFLIP protected PC-12 cells from both TNF- $\alpha$ and SVNI-induced apoptosis, we examined the role of this factor in the apoptosis induced by SVNI.

We first examined the effect of SVNI on TNF- $\alpha$ production in PC-12 cells. Infection of PC-12 with SVNI induced a large increase in the level of the mRNA of this factor as measured by semi-quantitative RT-PCR (Figure 4A). In contrast, the non-virulent strain SVA, did not increase the expression of TNF- $\alpha$ mRNA in PC-12 cells (data not shown). TNF- $\alpha$ protein was measured in the supernatants of SVNI-infected PC-12 cells by ELISA (Figure 4B). Untreated $\mathrm{PC}-12$ cells did not produce detectable levels of TNF- $\alpha$. Infection of the cells with SVNI induced a large increase in TNF- $\alpha$ production. Initial increase in TNF- $\alpha$ was observed $12 \mathrm{~h}$ following infection and plateau levels were obtained $24 \mathrm{~h}$ following infection. The production of TNF- $\alpha$ by SVNI infected cells preceded the onset of the apoptosis induced by the virus. The production of TNF- $\alpha$ in cells overexpressing vFLIP was determined after 12 (data not shown) and $24 \mathrm{~h}$ (Figure 4C) and was similar to that of control cells (Figure 4C).
$\mathbf{A}$

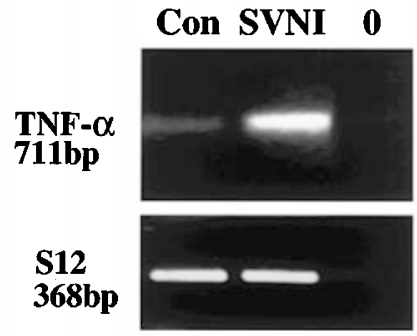

B

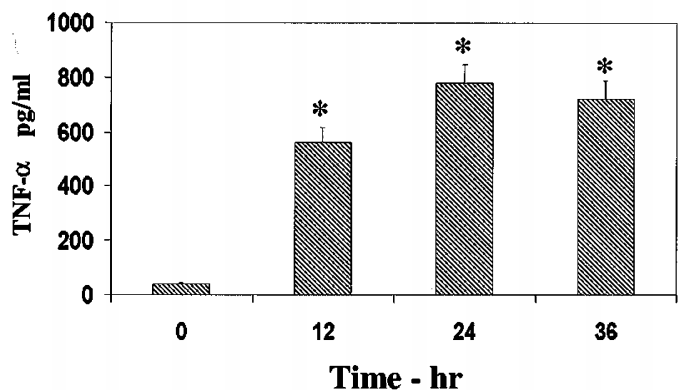

$\mathbf{C}$

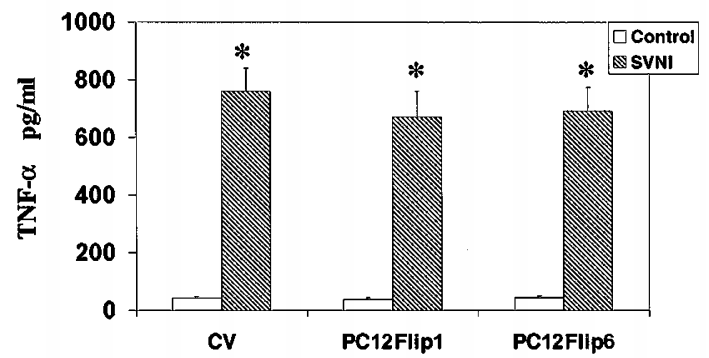

Figure 4 SVNI induces the production of TNF- $\alpha$ in PC-12 cells. PC-12 cells were infected with SVNI for $6 \mathrm{~h}$ and the mRNA level of TNF- $\alpha$ was determined using semi-quantitative RT-PCR. Reaction mixture with $1 \mu \mathrm{l}$ RNA instead of CDNA was used as a control to exclude any contamination (0). The RT-PCR products were visualized by ethidium bromide staining. Results of a representative experiment out of similar four are presented. (A) The secretion of TNF- $\alpha$ by infected PC-12 cells was determined after 12, 24 and $48 \mathrm{~h}$ (B) and in cells overexpressing vFlip after $24 \mathrm{~h}$ using ELISA Results shown are representative of three independent experiments. ${ }^{*} P<0.001$

\section{TNF- $\alpha$ plays a role in the apoptosis induced by SVNI}

To further examine the role of TNF- $\alpha$ in SVNI-induced cell apoptosis, we pretreated PC-12 cells with either anti-TNF- $\alpha$ antibody or soluble TNF- $\alpha$ receptor for $1 \mathrm{~h}$ prior to the infection of the cells with SVNI and examined cell apoptosis $48 \mathrm{~h}$ post infection. Infection of the cells with SVNI (5 M.O.I.) induced apoptosis in $62 \%$ of the cells within $36-48 \mathrm{~h}$ post infection. Pre-treatment of the cells for $1 \mathrm{~h}$ with either anti-TNF- $\alpha$ (Figure $5 \mathrm{~A}$ ) or soluble TNF- $\alpha$ receptor (Figure $5 \mathrm{~B}$ ) reduced significantly the apoptosis induced by SVNI to 32 and $27 \%$, respectively. Cells treated with either anti-TNF- $\alpha$ or soluble TNF- $\alpha$ receptor alone exhibited normal morphology and very low levels of cell apoptosis similar to that observed in control cells (data not shown). 
A

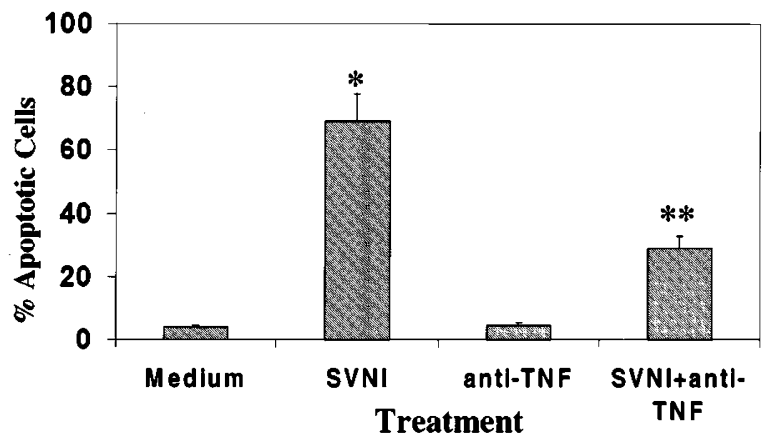

B

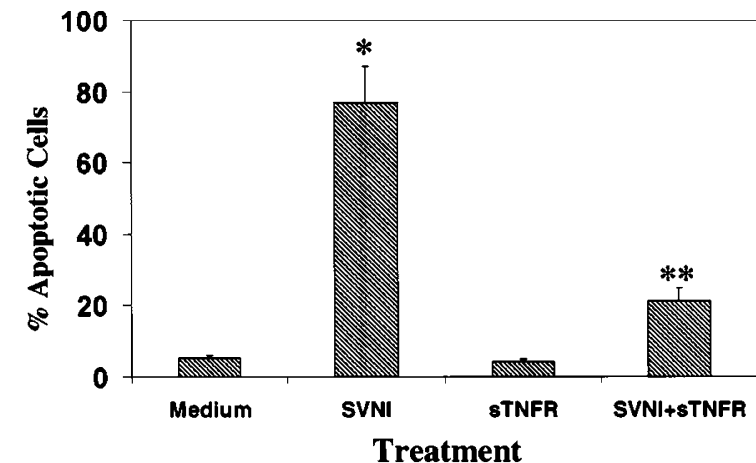

Figure 5 Anti-TNF- $\alpha$ antibodies and soluble TNF- $\alpha$ receptor inhibit apoptosis induced by SVNI in PC-12 cells. Cells were infected with SVNI in the absence and presence of a blocking anti-TNF- $\alpha$ antibody $(1.5 \mu \mathrm{g} / \mathrm{ml})(\mathbf{A})$ or soluble TNF$\alpha$ receptor $(1.0 \mu \mathrm{g} / \mathrm{ml})(B)$. Cell apoptosis was determined $48 \mathrm{~h}$ later using propidium iodide staining and FACS analysis. ${ }^{\star} P<0.001$, ${ }^{* \star} P<0.002$

\section{TNF-receptor1 (TNF $\alpha$-R1)-deficient mice are resistant to fatal SVNI infection}

The role of TNF- $\alpha$ signaling in the pathogenesis of SVNI was further examined using TNF $\alpha-\mathrm{R} 1$-deficient mice. $\mathrm{TNF} \alpha-\mathrm{R} 1-/-$ and wild type C57BL/6 mice were inoculated intracerebrally with SVNI (100 P.F.U.) and were then observed for paralysis and mortality. Our results indicate (Table 2) that following SVNI infection, all the infected control mice died after 7 days. In contrast, only $15.8 \%$ of the TNF $\alpha$ $\mathrm{R} 1-/-$ mice died and $41 \%$ of the mice developed paralysis. The paralysis of the knockout mice was observed after 7 days of infection as compared to $4-5$ days in the control mice, and the mortality started after $9-11$ days.

\section{Discussion}

In the present study we used the vFLIP encoded by the gammaherpesvirus HHV-8 ORF $\mathrm{K} 13$ gene as a probe to investigate the molecular mechanisms involved in SVNIinduced apoptosis. We demonstrated that overexpression of VFLIP in PC-12 cells protected these cells from apoptosis induced by SVNI, suggesting that replication of this virus activates apoptotic pathways employed by the TNF- $\alpha$ receptor superfamily.
Table 2 Paralysis and mortality of TNF- $\alpha$ R 1 deficient and control mice following SVNI infection

\begin{tabular}{lccc}
\hline Mice & No. of mice & Paralyzed & Dead \\
\hline TNF- $\alpha \mathrm{R} 1-/-$ & 19 & 8 & 3 \\
Wild type & 20 & 0 & $20^{\star}$ \\
\hline
\end{tabular}

TNF- $\alpha$ R1 knockout mice and C57BL/6 control mice were inoculated with $30 \mu$ of SVNI (100 P.F.U.). Mice were observed for mortality and paralysis for 21 days. ${ }^{*} P<0.001$

We further investigated the role of apoptosis in SVNI replication. Looking at virus progeny release we found comparable amounts of virions and protein released from SVNI-infected cells expressing VFLIP and control cells. Thus, vFLIP prevented neuronal cell death with no effect on the progeny virus production, unlike the anti-apoptotic protein Beclin, which inhibited neuronal cell death induced by SV and reduced SV replication. ${ }^{10}$ These results also indicate that efficient SVNI replication in culture does not depend on the induction of apoptosis as was demonstrated for HIV. ${ }^{27,28}$ Unlike Semliki Forest virus ${ }^{29}$ and influenza virus $^{30}$ the inhibition of apoptosis does not limit virus growth, and therefore does not have an anti-viral effect. Thus, we conclude that apoptosis in SVNI-infected host cells in vitro is not necessary for efficient virus replication.

Nava and colleagues reported that SV induced caspase activation and cleavage of intracellular target proteins in a manner that was characteristic of other cell death stimuli. ${ }^{12}$ They also showed that treatment with a broad inhibitor of cysteine proteases, expression of $\mathrm{CrmA}$, or expression of $\mathrm{Bcl}-\mathrm{XL}$ impaired virus-induced apoptosis. ${ }^{12}$ Similarly, we found that treatment of PC-12 cells with a caspase-8 inhibitor prevented virus-induced apoptosis, indicating that caspase-8, which is an important initiator that activates downstream caspases, is involved in the induction of cell death by SVNI infection.

We noticed a remarkable parallelism between SVNI and TNF- $\alpha$ regarding their abilities to induce apoptosis in PC-12 cells and their failure to do so in PC-12 expressing VFLIP. These findings suggest that TNF- $\alpha$ may play an important role in the apoptosis induced by SVNI. Indeed, in line with these observations, we found that infection of PC-12 cells with SVNI induced the production of TNF- $\alpha$ and treatment of the cells with anti-TNF- $\alpha$ antibody or with soluble TNF- $\alpha$ receptor significantly abrogated cell death induced by viral infection. Moreover, the non-neurovirulent strain SVA, which does not induce cell apoptosis, did not increase TNF- $\alpha$ production.

Several virally encoded FLIP genes have been identified in certain gammaherpesviruses as well as in the tumorigenic human molluscum contagiousum virus (MCV68). Cells expressing viral FLIPs encoded by the HHV-8, equine herpesvirus 2 (EHV-2), bovine herpes virus 4 (BHV-4) or MCV68 (vFLIP, E8, BORFE2, MC159, respectively) are protected from CD95 (Fas) and TNFR-1 induced apoptosis. ${ }^{16,23,31}$ Furthermore, MC159 and E8 inhibit cell death mediated by overexpression of the downstream adapters TRADD and FADD. ${ }^{16,23}$ Neither viral molecule inhibits FLICE-induced cell death, implying that once FLICE is 
active, vFLIP cannot inhibit its function. ${ }^{16}$ Substantial inhibition of TNFR-1-induced cell death, comparable with other characterized inhibitors such as CrmA and dominant negative FLICE was reported for C-FLIP. ${ }^{16}$

TNF- $\alpha$ is a proinflammatory cytokine that can selectively act to either activate or inhibit programmed cell death. ${ }^{32}$ The overall effects of TNF- $\alpha$ appear to be modulated by a protein complex bound to the cytoplasmic tail of the TNF- $\alpha$ receptors. $^{32}$ Evading cytolysis by TNF- $\alpha$ is an important aspect of various DNA and RNA viruses. ${ }^{33}$ Thus, several viruses, such as HHV-8, developed mechanisms to inhibit death receptor signaling which may facilitate the establishment of a persistent viral infection, or extend cell survival during productive infection to allow increased yields of virus progeny. ${ }^{5,17,23}$ There is also evidence that TNF- $\alpha$ can enhance the replication of some viruses such as HIV-1 and hepatitis $\mathrm{C}$ virus (HCV). ${ }^{6,34,35}$ TNF- $\alpha$ has been shown to be an important mediator of the pathogenesis of several viruses such as Newcastle disease virus, ${ }^{36}$ human herpesvirus- $6,{ }^{37} \mathrm{HCV}^{35}$ and African swine fever virus. ${ }^{26}$ We found that, infection with SVNI induced the production and secretion of TNF- $\alpha$ which in turn induced a characteristic receptor mediated programmed cell death. Moreover, TNF- $\alpha R 1$ deficient mice were resistant to fatal virus infection further suggesting an important role for TNF- $\alpha$ in the pathogenesis of SVNI-induced encephalitis. Possible pathophysiological roles of TNF- $\alpha$ in fatal SVNI infection include induction of neuronal apoptosis and inflammatory and stress responses in the CNS.

The role of apoptosis in virus life cycle and in the outcome of in vivo infection is not clear, however it is reasonable to assume that it may allow an efficient spread of progeny viruses with limited inflammatory response at the end of the infection cycle. In this respect, elevated production and secretion of TNF- $\alpha$ can indirectly activate apoptosis in uninfected cells that may augment the pathogenicity of the viral infection.

The detailed mechanisms by which VFLIP functions to inhibit Sindbis virus-induced neuronal cell death are currently unknown. Further studies on the mechanisms by which VFLIP interferes with cell death will provide insights into the apoptosis cascade induced by Sindbis virus infection.

\section{Materials and Methods}

\section{Materials}

The caspase inhibitor Z-IETD-FMK was purchased from Calbiochem (Darmstadt, Germany). TNF- $\alpha$ ELISA kit was from Biosource (Camarillo, CA, USA), neurotralizing anti-TNF- $\alpha$ antibody and soluble TNF- $\alpha$ receptor I were purchased from Research Diagnostics Inc (Flanders, NJ, USA). TNF- $\alpha \mathrm{R} 1-/-$ mice were purchased from Jackson Laboratories.

\section{Viruses}

Variants of Sindbis virus used in this study were previously described. ${ }^{21}$ Briefly, the neurovirulent strain SVNI was isolated by serial passages of a SV strain in brains of suckling and weanling mice.
The non-neurovirulent variant, SVA, has been isolated by plaque purification of the same original SV strain. The Vero monkey kidney epithelial cell line was grown in Modified Eagle's Medium (MEM) supplemented with $10 \%$ fetal bovine serum (FBS).

\section{Virus plaque assay in Vero cells}

For quantification of SV in Vero cells, the original plaque technique was performed as already described. ${ }^{38}$ Briefly, a dilution of virus was added to Vero cell monolayers in petri dishes and incubated at $37^{\circ} \mathrm{C}$ for $1 \mathrm{~h}$ to permit viral absorption. The monolayer was overlaid with MEMx2 and tragacnath (Gum tragacnath Grade III, Sigma) containing $2 \% \mathrm{FBS}$ and $2.4 \% \mathrm{NaHCO}_{3}$. Cultures were incubated $\left(37^{\circ} \mathrm{C}, 5 \% \mathrm{CO}_{2}\right)$ for $48 \mathrm{~h}$ and plaques were counted after staining with $0.05 \%$ neutral red. $^{39}$

\section{In vivo studies}

TNF $\alpha \mathrm{R} 1-/-(\mathrm{TNF}-\alpha \mathrm{R} 1)$ mice ${ }^{40}$ and C57BL/6 control mice (4 weeks) were inoculated intracerebrally with 100 P.F.U. SVNI in $30 \mu$ l saline. Cells were observed for 21 days and the degree of paralysis and mortality was determined.

\section{vFLIP expression plasmid}

Glutathione S-transferase (GST) fusion protein was constructed by cloning the entire open reading frame (ORF) encoding the human herpesvirus 8 (HHV-8) vFLIP (ORF K13) in-frame with GST protein in PALEX by using the polymerase chain reaction (PCR) primers $5^{\prime}$ CAAGCCGTCGACATGGCCACT-3' and 5'-CAGCTTGTAAGCTTTGGTGTATGG-3' (the cloning sites Sall and Hindll are underlined) and $\mathrm{BC}-1$ genomic DNA as a template (kindly provided from Drs PS Moore and Y Chang). The PCR product was excised from pALEX by ECORI and Notl digestion, and subcloned in-frame into the expression vector pcDNA/His3.1B (Invitrogen, San Diego, CA, USA) to generate a mammalian expression plasmid.

\section{PC-12 cell culture, transfection and infection}

Rat pheochromocytoma PC-12 cells were grown in DMEM supplemented with $10 \%$ horse-serum, $5 \%$ heat-inactivated FBS, $2 \mathrm{mM}$ glutamine, penicillin $(50 \mathrm{U} / \mathrm{ml})$ and streptomycin $(0.05 \mathrm{mg} / \mathrm{ml}) .1 \times 10^{5}$ cells $/ \mathrm{ml}$ were seeded on tissue culture dishes $\left(10 \mathrm{~cm}^{2}\right)$ and transfected with either the empty vector or with the vFLIP expression vector using Lipofectamine (Gibco BRL Life Technologies, Gaithersburg, MD, USA) as described elsewhere. ${ }^{41}$ Experiments were routinely carried out on one pool and two clones of stable transfected cells.

For virus infection, growth medium was removed from the cultures and replaced with $10 \%$ volume of medium containing virus (5 M.O.I.). Viruses were absorbed to the cells for $1 \mathrm{~h}$ at $37^{\circ} \mathrm{C}$, after which they were removed and the cultures were washed twice. Fresh growth medium was added and the cultures were incubated at $37^{\circ} \mathrm{C}$.

\section{Preparation of mRNA and RT - PCR analysis}

Total RNA was extracted from PC-12 cells with TRI Reagent (MRC, Cincinnati, OH, USA) according to Chomczynski and Sacchi. ${ }^{42}$ Five micrograms of total RNA was reverse-transcribed into cDNA with an Expand $^{\mathrm{TM}}$ Reverse transcriptase (Boheringer, Germany), using 100 pmoles of the Oligo(dT) ${ }_{15}$ according to protocol provided by manufacture. 
Relative levels of TNF- $\alpha$ mRNA and of the ribosomal protein S-12 mRNA were measured using a semi-quantitative reverse transcriptase (RT) - PCR. The cDNA product, $1 \mu \mathrm{g}$ - for PCR with TNF- $\alpha$ primers and $0.25 \mu \mathrm{g}$-for PCR with $\mathrm{S}-12$ primers, was resuspended in a total volume of $50 \mu$ l containing 1 units of Taq DNA polymerase (Appligene, France), $200 \mu \mathrm{M}$ each of dATP, dCTP, dGTP, dTTP, $1 \times$ reaction buffer provided by the manufacture and $50 \mathrm{pmol}$ of both forward and reverse primers. TNF- $\alpha$ fragment (374 bp) was obtained using the following primers for the murine TNF- $\alpha$ : $3^{\prime}-$ TTGACCTCAGCGCTGAGTTG; 5'- CCTGTAGCCCACGTCGTAGC. Primers span exonintron junctions as not to amplify contaminating genomic DNA. Amplification step consisted of $95^{\circ} \mathrm{C}$ for $3 \mathrm{~min}$ and the indicated number of cycles of $95^{\circ} \mathrm{C}$ for $30 \mathrm{~s}, 55^{\circ} \mathrm{C}$ for $1 \mathrm{~min}$ and $70^{\circ} \mathrm{C}$ for $1 \mathrm{~min}$. Each cDNA was amplified in serial of 25,30 and 40 cycles to obtain data within the linear-range of the assay. These conditions were optimal for reverse transcription and amplification of TNF- $\alpha$ ( 40 cycles) and S-12 (25 cycles). PCR products were size-fractionated by electrophoresis on $1.5 \%$ agarose gels and ethidium-bromide stained.

\section{Measurement of TNF- $\alpha$ production}

Supernatants of controls and SVNI infected PC12 cells were collected and levels of TNF- $\alpha$ were determined by a commercial ELISA kit (Biosource, Camarillo, CA, USA). The sensitivity of TNF- $\alpha$ detection in this assay system was about $10-20 \mathrm{pg} / \mathrm{ml}$.

\section{Preparation of cell homogenates}

Cells were washed and resuspended in serum-free medium. The plates were placed on ice, scraped with a rubber policeman and centrifuged at 1400 r.p.m. for $10 \mathrm{~min}$. The supernatants were aspirated and the cell pellets were resuspended in $100 \mu \mathrm{l}$ of lysis buffer (25 mM Tris- $\mathrm{HCl}$, pH 7.4, $50 \mathrm{mM} \mathrm{NaCl}, 0.5 \% \mathrm{Na}$ deoxycholate; 2\% NP-40; $0.2 \%$ SDS; $1 \mathrm{mM}$ PMSF; $50 \mu \mathrm{g} / \mathrm{ml}$ aprotinin; $50 \mu \mathrm{M}$ leupeptin; $0.5 \mathrm{mM} \mathrm{Na}_{3} \mathrm{VO}_{4}$ ) on ice for $15 \mathrm{~min}$. The cell lysates were centrifuged for $15 \mathrm{~min}$ at 14000 r.p.m. in an Eppendorf microcentrifuge; the supernatants were removed and $2 \times$ sample buffer was added to them.

\section{Immunoblot analysis}

Lysates (30 $\mu$ g protein) were subjected to SDS - PAGE (10\%) followed by transfer to nitrocellulose membranes. A similar protein content of the different samples was verified by staining the membranes with $0.1 \%$ Ponceau S solution in $5 \%$ acetic acid. The nitrocellulose membranes were blocked with $5 \%$ dry milk in phosphate-buffered saline and subsequently stained with the primary antibody. Specific reactive bands were detected using a goat anti-rabbit or goat antimouse IgG conjugated to horseradish peroxidase (BioRad, Hercules, CA, USA) and the immunoreactive bands were visualized by the ECL Western blotting detection kit (Amersham, Arlington Heights, IL, USA).

\section{Measurement of apoptosis}

Cell apoptosis was measured using propidium iodide (PI) staining and analysis by flow cytometry or by ELISA using anti-histonel antibodies. Cells $\left(1 \times 10^{6} / \mathrm{ml}\right)$ were plated in 6 -well plates and treated with the indicated treatments for $24 \mathrm{~h}$. For PI staining, detached and trypsinized adherent cells were pooled, fixed in $70 \%$ ethanol for $1 \mathrm{~h}$ on ice, washed with PBS and treated for 15 min with RNAse $(50 \mu \mathrm{M})$ at room temperature. Cells were then stained with propidium iodide $(5 \mu \mathrm{g} / \mathrm{ml})$ and analyzed on a Becton-Dickinson cell sorter. Cells in the sub-G1 population were considered as apoptotic cells. For anti- histonel ELISA, fragmented DNA was extracted from the cells and was incubated in 96-well plates coated with anti-histone 1 antibodies for $2 \mathrm{~h}$. Plates were then washed and incubated with anti-DNA antibodies conjugated to peroxidase for an additional $2 \mathrm{~h}$.

\section{Statistical analysis}

The results are presented as the mean values \pm S.E. Data were analyzed using ANOVA and a paired Student's $t$-test to determine the level of significance between the different groups.

\section{Acknowledgements}

This work was supported by Israel Science Foundation grant 72696-16.6. We wish to thank. Paula Schneider for the excellent technical assistance and Avrille Goldreich for the skillful preparation of the manuscript.

\section{References}

1. Raff MC (1992) Social controls on cell survival and cell death. Nature 356: 397 400

2. Thompson CB (1995) Apoptosis in the pathogenesis and treatment of disease. Science 267: $1456-1462$

3. Wertz IE and Hanley MR (1996) Diverse molecular provocation of programmed cell death. Trends Biochem. Sci. 21: 359-364

4. White $E$ (1996) Life, death, and the pursuit of apoptosis. Genes Dev. 10: 1-15

5. Teodoro JG and Branton PE (1997) Regulation of apoptosis by viral gene products. J. Virol. 71: $1739-1746$

6. Roulston A, Marcellus RC and Branton PE (1999) Viruses and apoptosis. Ann. Rev. Microbiol. 53: 577-628

7. Griffin DE and Hardwick JM (1997) Regulators of apoptosis on the road to persistent alphavirus infection. Annu. Rev. Microbiol. 51: 565-592

8. Griffin DE and Hardwick JM (1999) Perspective: virus infections and the death of neurons. Trends Microbiol. 7: 155-160

9. Levine B, Huang Q, Isaacs JT, Reed JC, Griffin DE and Hardwick JM (1993) Conversion of lytic to persistent alphavirus infection by the bcl-2 cellular oncogene. Nature 361: 739-742

10. Liang XH, Kleeman LK, Jiang HH, Gordon G, Goldman JE, Berry G, Herman B and Levine B (1998) Protection against fatal Sindbis virus encephalitis by beclin, a novel Bcl-2-interacting protein. J. Virol. 72: 8586-8596

11. Griffin DE (1998) A review of alphavirus replication in neurons. Neurosci. Biobehav. Rev. 22: 721-723

12. Nava VE, Rosen A, Veliuona MA, Clem RJ, Levine B and Hardwick JM (1998) Sindbis virus induces apoptosis through a caspase-dependent, CrmA-sensitive pathway. J. Virol. 72: 452-459

13. Wallach D (1997) Cell death induction by TNF: a matter of self control. Trends Biochem. Sci. 22: 107-109

14. Porter AG (1999) Protein translocation in apoptosis. Trends Cell. Biol. 9: 394 401

15. Cohen GM (1997) Caspases: the executioners of apoptosis. Biochem. J. 326: $1-16$

16. Hu S, Vincenz C, Buller M and Dixit VM (1997) A novel family of viral death effector domain-containing molecules that inhibit both CD-95- and tumor necrosis factor receptor-1-induced apoptosis. J. Biol. Chem. 272: 9621-9624

17. Thome M, Schneider P, Hofmann K, Fickenscher H, Meinl E, Neipel F, Mattmann C, Burns K, Bodmer JL, Schroter M, Scaffidi C, Krammer PH, Peter ME and Tschopp J (1997) Viral FLICE-inhibitory proteins (FLIPs) prevent apoptosis induced by death receptors. Nature 386: 517-521

18. Goltsev YV, Kovalenko AV, Arnold E, Varfolomeev EE, Brodianskii VM and Wallach D (1997) CASH, a novel caspase homologue with death effector domains. J. Biol. Chem. 272: 19641-19644

19. Irmler M, Thome M, Hahne M, Schneider P, Hofmann K, Steiner V, Bodmer JL, Schroter M, Burns K, Mattmann C, Rimoldi D, French LE and Tschopp J (1997) Inhibition of death receptor signals by cellular FLIP. Nature 388: 190-195 
20. Srinivasula SM, Ahmad M, Ottilie $S$, Bullrich F, Banks $S$, Wang $Y$, FernandesAlnemri T, Croce CM, Litwack G, Tomaselli KJ, Armstrong RC and Alnemri ES (1997) FLAME-1, a novel FADD-like anti-apoptotic molecule that regulates Fas/ TNFR1-induced apoptosis. J. Biol. Chem. 272: 18542-18545

21. Lustig S, Halevy M, Ben Nathan D and Akov Y (1992) A novel variant of Sindbis virus is both neurovirulent and neuroinvasive in adult mice. Arch. Virol. 122: $237-248$

22. Appel E, Katzoff A, Ben Moshe T, Kazimirsky G, Kobiler D, Lustig S and Brodie C (2000) Differential regulation of bcl-2 and bax expression in cells infected with virulent and nonvirulent strains of sindbis virus [in process citation]. Virology 276: $238-242$

23. Bertin J, Armstrong RC, Ottilie S, Martin DA, Wang Y, Banks S, Wang GH, Senkevich TG, Alnemri ES, Moss B, Lenardo MJ, Tomaselli KJ and Cohen JI (1997) Death effector domain-containing herpesvirus and poxvirus proteins inhibit both Fas- and TNFR1-induced apoptosis. Proc. Natl. Acad. Sci. USA 94: $1172-1176$

24. Martin DA, Siegel RM, Zheng L and Lenardo MJ (1998) Membrane oligomerization and cleavage activates the caspase-8 (FLICE/MACHalpha 1) death signal. J. Biol. Chem. 273: 4345-4349

25. Brodie C, Weizman N, Katzoff A, Lustig S and Kobiler D (1997) Astrocyte activation by Sindbis virus: expression of GFAP, cytokines, and adhesion molecules. Glia 19: 275-285

26. Gomez dM, Ortuno E, Fernandez-Zapatero P, Alonso F, Alonso C, Ezquerra A and Dominguez J (1999) African swine fever virus infection induces tumor necrosis factor alpha production: implications in pathogenesis. J. Virol. 73: $2173-2180$

27. Antoni BA, Sabbatini P, Rabson AB and White E (1995) Inhibition of apoptosis in human immunodeficiency virus-infected cells enhances virus production and facilitates persistent infection. J. Virol. 69: 2384-2392

28. Chinnaiyan AM, Woffendin C, Dixit VM and Nabel GJ (1997) The inhibition of proapoptotic ICE-like proteases enhances HIV replication. Nat. Med. 3: 333-337

29. Scallan MF, Allsopp TE and Fazakerley JK (1997) bcl-2 acts early to restrict Semliki Forest virus replication and delays virus-induced programmed cell death. J. Virol. 71: 1583-1590

30. Olsen CW, Kehren JC, Dybdahl-Sissoko NR and Hinshaw VS (1996) bcl-2 alters influenza virus yield, spread, and hemagglutinin glycosylation. J. Virol. 70:663666

31. Chaudhary PM, Jasmin A, Eby MT and Hood L (1999) Modulation of the NFkappa $B$ pathway by virally encoded death effector domains-containing proteins. Oncogene 18: $5738-5746$
32. Wallach D, Varfolomeev EE, Malinin NL, Goltsev YV, Kovalenko AV and Boldin MP (1999) Tumor necrosis factor receptor and Fas signaling mechanisms. Annu. Rev. Immunol. 17: 331-367

33. Vilcek J and Sen GC (1996) Interferons and other cytokines. In Fields Virology, Fields BN, Knipe DM and Howley PM, eds (Philadelphia: Lippincott-Raven) pp. $375-399$

34. Osborn L, Kunkel S and Nabel GJ (1989) Tumor necrosis factor alpha and interleukin 1 stimulate the human immunodeficiency virus enhancer by activation of the nuclear factor kappa B. Proc. Natl. Acad. Sci. USA 86: 2336-2340

35. Zhu N, Khoshnan A, Schneider R, Matsumoto M, Dennert G, Ware C and Lai MM (1998) Hepatitis $C$ virus core protein binds to the cytoplasmic domain of tumo necrosis factor (TNF) receptor 1 and enhances TNF-induced apoptosis. J. Virol. 72: $3691-3697$

36. Lorence RM, Rood PA and Kelley KW (1988) Newcastle disease virus as an antineoplastic agent: induction of tumor necrosis factor-alpha and augmentation of its cytotoxicity. J. Natl. Cancer Inst. 80: 1305-1312

37. Inoue Y, Yasukawa M and Fujita S (1997) Induction of T-cell apoptosis by human herpesvirus 6. J. Virol. 71: 3751-3759

38. Strauss EG, Lenches EM and Strauss JH (1976) Mutants of sindbis virus. I. Isolation and partial characterization of 89 new temperature-sensitive mutants. Virology 74: $154-168$

39. Kobiler D, Rice CM, Brodie C, Shahar A, Dubuisson J, Halevy M and Lustig S (1999) A single nucleotide change in the $5^{\prime}$ noncoding region of Sindbis virus confers neurovirulence in rats. J. Virol. 73: 10440-10446

40. Pfeffer K, Matsuyama T, Kundig TM, Wakeham A, Kishihara K, Shahinian A, Wiegmann K, Ohashi PS, Kronke M and Mak TW (1993) Mice deficient for the $55 \mathrm{kd}$ tumor necrosis factor receptor are resistant to endotoxic shock, yet succumb to L. monocytogenes infection. Cell 73: 457-467

41. Brodie C, Bogi K, Acs P, Lazarovici P, Petrovics G, Anderson WB and Blumberg PM (1999) Protein kinase C-epsilon plays a role in neurite outgrowth in response to epidermal growth factor and nerve growth factor in PC12 cells. Cell Growth Differ. 10: 183-191

42. Chomczynski $P$ and Sacchi N (1987) Single step method of RNA isolation by acid guanidinium thiocyanate-phenol-chloroform extraction. Anal. Biochem. 162 $156-159$ 